\title{
ANALYSIS OF THE POSSIBILITY TO ASSESS THE OCCURRENCE OF HIDDEN CORROSION IN LAP JOINTS USING ACTIVE THERMOGRAPHY
}

\author{
Lukasz Kornas \\ Krzysztof Dragan \\ Air Force Institute of Technology, \\ Warsaw, Poland
}

\begin{abstract}
The article details the NDT technique of pulse thermography used for objective diagnosis of riveted lap joints construction. The degradation of materials manifesting in corrosion is inherent in the process of aircraft operation. One type of corrosion is galvanic corrosion occurring in the overlap joints (known as hidden corrosion). As a result of the potential difference between the two layers of the aluminum alloy skin, there occurs the phenomenon of oxidation of the material, producing corrosion products in the form of oxide compounds characterized by heat properties different than those of the base material. Active thermography techniques allow observing infrared energy, which changes due to the difference of thermal properties of the tested materials.
\end{abstract}

\section{INTRODUCTION}

Corrosivity is a very important phenomenon unfavourably affecting materials used in aviation. Corrosivity necessitates continuous aircraft surveillance during operation. The effect of corrosion processes is the damage of the material observed mainly on the surface of the material in the form of an accumulation of solid compounds such as oxides, rust and scale resulting from chemical reactions. These chemical reactions are caused by changing weather conditions, increased humidity and the working environment such as contact with sea water. In many cases, the aircraft structural component exposed to corrosion is the plated area of the lap riveted joints. As a result of the difference in potential at the interface between two materials, oxidation of the material occurs creating corrosion products in the form of metal oxides. In the case of aircraft structures made of light alloys (usually aluminium alloys), these are mostly aluminium oxides $\mathrm{Al}_{2} \mathrm{O}_{2} * 3 \mathrm{H}_{2} \mathrm{O}$, whose molar volume is greater than that of pure aluminium. They accumulate between adjacent materials, causing local surface deformations. Continuous process of creating metal oxide contributes to fatigue. Ignoring this phenomenon may lead to deterioration in strength properties of joined materials as well as damage of the rivet connecting them. It is a kind of hidden corrosion called pillowing. 


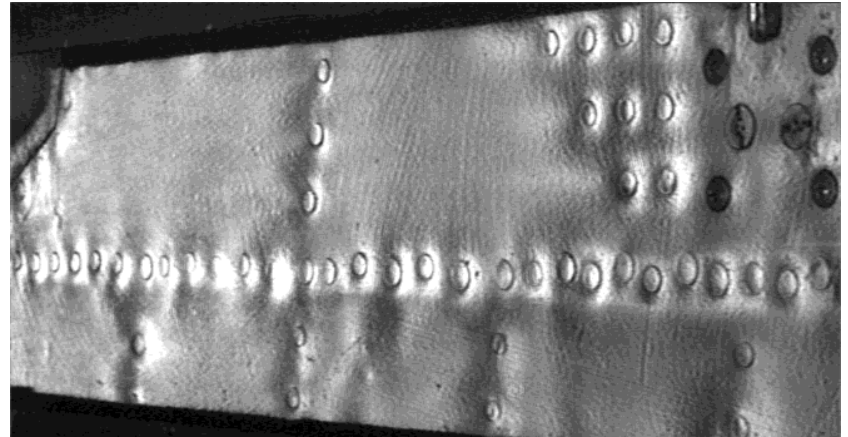

Fig. 1. Hidden corrosion (pillowing), the result of test with the use of DAIS system[1]

The DAIS system measures the degree of surface deformation caused by the presence of solid metal compounds at the boundary between two materials. Using a number of different test techniques enables better verification of the research results. The authors used a pulsed thermography technique, which allows the registration of changes in infrared radiation emitted by the material. Based on the fundamental thermal coefficients (table. 1) for specific materials, the authors conducted preliminary tests to confirm the presented thesis.

Table 1. Basic thermophysical properties of selected materials[3].

\begin{tabular}{|c|c|c|c|c|c|c|}
\hline Materials & $\begin{array}{l}\text { Density } \\
{\left[\mathrm{g} / \mathrm{cm}^{3}\right]}\end{array}$ & $\begin{array}{c}\text { Specific } \\
\text { heat } \\
{\left[\mathrm{J} / \mathrm{kg}^{*} \mathrm{~K}\right]}\end{array}$ & $\begin{array}{c}\text { Thermal } \\
\text { conductivity } \\
\lambda \\
{\left[\mathrm{W} / \mathrm{m}^{*} \mathrm{~K}\right]}\end{array}$ & $\begin{array}{c}\text { Thermal } \\
\text { diffusivity } \\
A \\
{\left[\mathrm{~m}^{2} / \mathrm{s}\right]}\end{array}$ & $\begin{array}{c}\text { Thermal } \\
\text { interia } \\
E \\
{\left[\mathrm{~W}^{*} \mathrm{~s} / / 2 / \mathrm{m}^{2} \mathrm{~K}\right]}\end{array}$ & $\begin{array}{c}\text { Emissivity } \\
\varepsilon\end{array}$ \\
\hline $\begin{array}{l}\text { Aluminium } \\
\text { (duraluminium) }\end{array}$ & $\begin{array}{c}2,720 \\
(2,750)\end{array}$ & $\begin{array}{c}897 \\
(913)\end{array}$ & $\begin{array}{c}244 \\
(165)\end{array}$ & $(0,64)$ & $\begin{array}{c}- \\
(20538)\end{array}$ & $0,04-0,2$ \\
\hline Water & 1 & 4186 & 0,586 & 0,140 & 1570 & - \\
\hline Air & 1,23 & 1005 & 0,07 & 58,0 & 9,19 & - \\
\hline $\begin{array}{l}\text { Aluminum } \\
\text { oxides }\left(\mathrm{Al}_{2} \mathrm{O}_{3}\right)\end{array}$ & 3,980 & 1090 & 36,0 & - & - & 0,6 \\
\hline $\begin{array}{l}\text { Other } \\
\text { Brass } \\
\text { Copper } \\
\text { Carbon Steel }\end{array}$ & $\begin{array}{l}8,600 \\
8,900 \\
7,850\end{array}$ & $\begin{array}{l}381 \\
380 \\
470\end{array}$ & $\begin{array}{c}100-110 \\
380 \\
46-50\end{array}$ & $\begin{array}{c}30,52-33,57 \\
112 \\
12,5-13,5\end{array}$ & $\begin{array}{c}18101-1898 \\
35849 \\
13027-13582\end{array}$ & $\begin{array}{l}- \\
- \\
-\end{array}$ \\
\hline
\end{tabular}

\section{TEST RESULTS}

While performing preliminary tests, samples with the damaged anti-corrosion coating from the wing flap of Su-22 aircraft were used (Fig.2). The tests were carried out with pulsed thermography using EchoTherm. Hidden corrosion can manifest itself through the paint coating damage such as cracks, blowholes, etc. This causes the varnish layer flaking due to lack of adhesion to the surface. Anti-corrosion coating damage is caused by adverse external factors such as humidity, exposure to sea water or by contaminants introduced during the production stage. Thermographic results of the damaged paint coating are shown on the thermograph below (Fig. 2). 

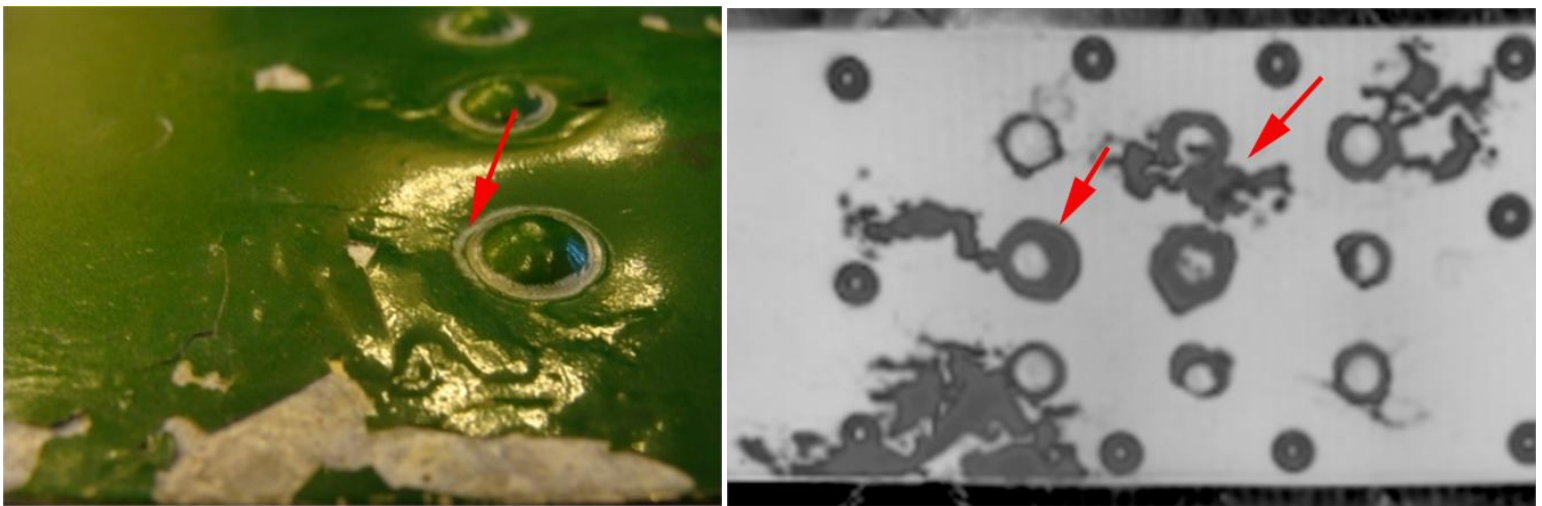

Fig.2. a) damaged anti-corrosion paint coating,

b) thermograph of damaged anti-corrosion paint coating

Hidden corrosion manifests itself mostly as a result of the material oxidation creating solid oxide compounds. In aircraft structures, because of the materials used in the plating, corrosion products are aluminium oxides. The resulting compounds are characterized by other thermal properties allowing their detection with thermographic methods. Preliminary tests were carried out on the object with riveted joints. Solids with other thermal parameters in relation to the base material (aluminium alloy) were introduced to lap joints. They cause disruption in homogenous intensity of infrared radiation emission on the surface of the tested object. The thermograph of the sample tested and the diagram illustrating the surface intensity of infrared radiation during cooling of the material are presented below (Fig.3).

Sample lap joints
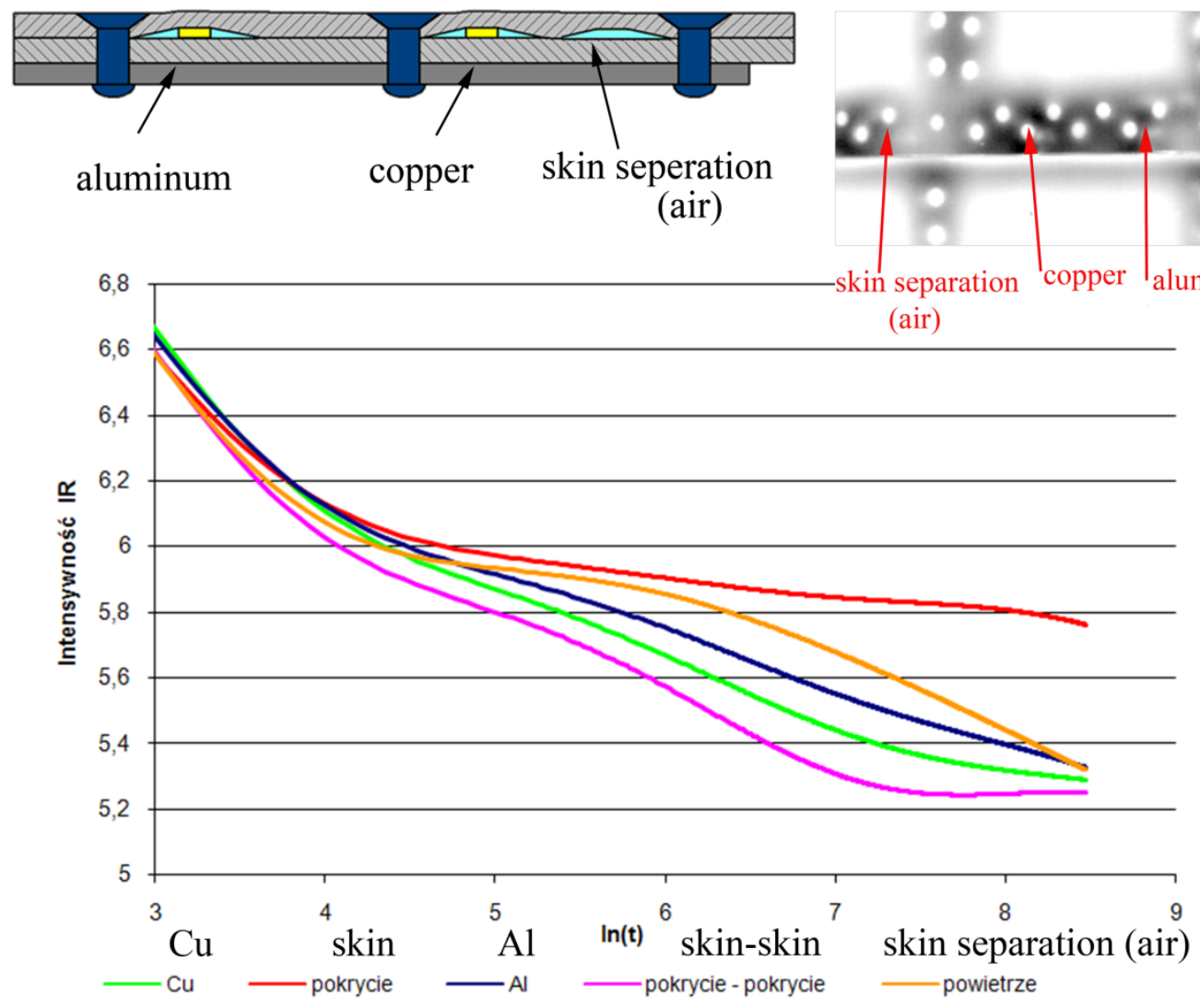

Thermograph

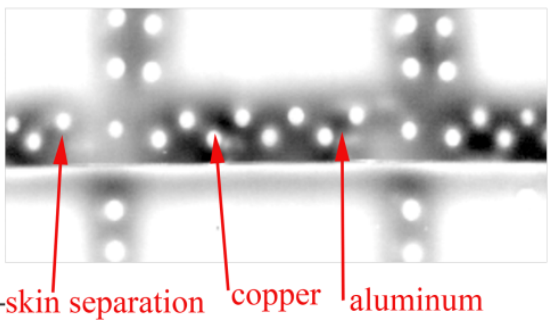

(air)

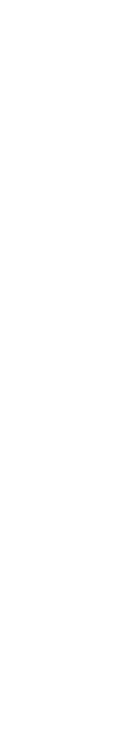

Fig.3. Thermograph of the sample tested and the diagram illustrating the surface intensity 


\section{SUMMARY}

Preliminary results with the pulsed thermography method show the capabilities of the selected technique for hidden corrosion evaluation in aircraft structures. With the method used we can easily and quickly check the quality and correctness of paint coating at the stage of application, as well as its status during operation (Fig. 2). The infrared technique offers opportunities for detecting material inclusions due to differences in thermal properties. With this technique a different infrared radiation wavelength is detected in the area where material compounds of different thermal parameters are present (Fig. 3).

\section{REFERENCES}

[1] Dragan, K. \& Klimaszewski, S. (2003). Rozpoznanie i klasyfikacja korozji ukrytej w konstrukcji statków powietrznych za pomocą systemu DAIS. 32 Krajowa Konferencja Badań Niszczących, 27-30.10.2003 Międzyzdroje.

[2] Oliferuk, W. (2008). Termografia podczerwieni $w$ nieniszczacych badaniach materiałów $i$ urzqdzeń. Warszawa: Biuro Gamma.

[3] Świderski, W. (2010). Metody termograficzne $w$ nieniszczqcych badaniach materiatów kompozytowych do zastosowania specjalnych. Wojskowy Instytut Techniczny Uzbrojenia, Zielonka.

[4] Matzkanin, G.A. \& Yolken, H.T. (2007). Nondestructive Evaluation Techniques for Detecting Hidden Corrosion, The AMMTIAC Quarterly. 2(2), 3-6.

[5] Vavilov, V.R. (2003). Non-contact one-sided evaluation of hidden corrosion in metallic constructions by using transient infrared thermography. Revista de Metalurgia. (2003), 235242.

[6] Perez, I. \& Kulowitch, P. Thermography for characteriziation of corrosion damage. Naval Air Warfare Center, Aircraft Division Patuxent River MD 20670.

[7] Shepard, S.M. (2001). Thermographic Detection of Front and Back Surface Corrosion. Thermal Wave Imaging, Inc. Ferndale, MI 48220. 